\title{
The use of modified silica to control the morphology of polyamide 11 and poly(phenylene oxide) blends
}

\author{
Regina Jeziórska ${ }^{1), ~ *) ~(O R C I D ~ I D: ~ 0000-0001-6999-6414), ~ A g n i e s z k a ~ S z a d k o w s k a ~}{ }^{1)}$ (0000-0003-3144-7422),

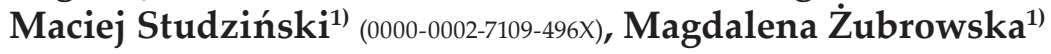 \\ DOI: dx.doi.org/10.14314/polimery.2021.7.3
}

\begin{abstract}
Silica having amine functional groups $\left(\mathrm{A}-\mathrm{SiO}_{2}\right)$ obtained by the sol-gel process was used to improve compatibility of polyamide 11 and poly(phenylene oxide) (PA11/PPO 80/20) blend via reactive extrusion in a co-rotating twin screw extruder. Amine functional groups of $\mathrm{A}-\mathrm{SiO}_{2}$ can react with the carboxyl groups of PA11 to form graft copolymer with PA11 which can efficiently control the phase morphology of the blend. Silica, thanks to the reinforcing effect, significantly increased stiffness of PA11/PPO blend. On the other hand, it greatly improved impact strength and reduced the crystallinity without affecting the crystallization temperature of PA11due to excellent compatibilizing effect. SEM results showed that despite the lower content of PPO, it formed a continuous phase and PA11 - a dispersed. The addition of $\mathrm{A}-\mathrm{SiO}_{2}$ changed the morphology from the droplet-matrix to co-continuous with interpenetrating phases. The greatest size-reduction of both phases, reflecting the highest impact toughness, was observed for the content of $3 \mathrm{wt} \% \mathrm{~A}-\mathrm{SiO}_{2}$. With a higher silica loading, phase inversion was observed with the reappearance of the droplet structure, resulting in a slight decrease in impact strength and significant in elongation at break. TGA showed that the composites exhibited better thermal properties as evidenced by the higher initial degradation temperature $\left(T_{\text {onse }}\right)$ and the maximum weight loss rate temperature $\left(T_{\max }\right)$.
\end{abstract}

Keywords: modified silica, PA11, PPO, blends, morphology, mechanical properties.

\section{Zastosowanie modyfikowanej krzemionki do kontroli struktury mieszanin poliamidu $11 \mathrm{z}$ poli(tlenkiem fenylenu)}

Streszczenie: Otrzymaną $\mathrm{w}$ procesie zol-żel krzemionkę zawierającą aminowe grupy funkcyjne $\left(\mathrm{A}-\mathrm{SiO}_{2}\right)$ zastosowano do poprawy kompatybilności mieszaniny poliamidu 11 z poli(tlenkiem fenylenu) (PA11/ PPO 80/20). Proces prowadzono metodą reaktywnego wytłaczania przy użyciu dwuślimakowej wytłaczarki współbieżnej. Aminowe grupy funkcyjne $\mathrm{A}-\mathrm{SiO}_{2}$ mogą reagować z grupami karboksylowymi PA11 i tworzyć kopolimery szczepione z PA11, co może skutecznie kontrolować strukturę mieszaniny. Krzemionka, dzięki efektowi wzmacniającemu, znacznie zwiększyła sztywność mieszaniny PA11/PPO. Natomiast, dzięki doskonałemu efektowi kompatybilizacji poprawiła udarność i zmniejszyła stopień krystaliczności mieszaniny bez wpływu na temperaturę krystalizacji PA11. Wyniki SEM wykazały, że pomimo mniejszego udziału, PPO tworzy fazę ciągłą, a PA11 zdyspergowaną. Dodatek krzemionki zmienił strukturę z kropelkowej na ciągłą z wzajemnie przenikającymi się fazami. Przy zawartości 3\% mas. A- $\mathrm{SiO}_{2}$ zaobserwowano największe rozdrobnienie obu faz i najwyższą udarność. Przy większej zawartości A-SiO ${ }_{2}$ nastąpiła inwersja faz z ponownym pojawieniem się struktury kropelkowej, co skutkowało zmniejszeniem udarności i wydłużenia przy zerwaniu. Badania TGA wykazały, że kompozyty charakteryzują się lepszymi właściwościami termicznymi, o czym świadczy wyższa temperatura początku rozkładu i temperatura maksymalnej szybkości rozkładu.

Słowa kluczowe: modyfikowana krzemionka, PA11, PPO, mieszaniny, struktura, właściwości mechaniczne.

Nowadays, biopolymers are a good alternative to petroleum-based products. Among them, fully bio-based

1) Łukasiewicz Research Network - Industrial Chemistry Institute, Rydygiera 8, 01-793 Warsaw, Poland.

*) Author for correspondence: Regina.Jeziorska@ichp.pl (no-biodegradable) polyamide 11 (PA11) is a semi-crystalline thermoplastic with a low moisture permeability, allowing a wide range of applications, from the automotive to the food packaging industry. PA11 is produced using 11-aminoundecanoic acid derived from castor oil, which is extracted from the Ricinus communis, a common 
plant in Asia. The variety of fatty acids contained in the oil, with the right refining process, leads to a huge variety of products used in the industry [1].

Few studies have been carried out on PA11 composites. Polyamide 11 had been successfully reinforced with softwood stone ground-wood fibers [2], flax fibers [3-5], montmorillonite [6], and silane grafted titanate nanotubes [7]. Recently, Sahnoune et al. [8] have reported that functionalized halloysite enhanced thermal properties of PA11/SEBS-g-MA 85/15 blend without affecting polyamide crystallization. In addition, toughness was significantly improved as a result of good stress transfer from the matrix to the functionalized halloysite agglomerates surrounded by SEBS-g-MA.

Blends of bio-based PA11 and poly(phenylene oxide) (PPO) are interesting as a high- performance materials with enormous environmental benefits. PPO offers high dimension and thermal stability, while PA11 exhibits strong chemical and UV resistance as well as low melt viscosity [9-12]. The aim of this study is to combine the advantages of PA11 and PPO. However, polyamides and PPO are thermodynamically immiscible, which may result in deterioration of impact strength and elongation at break compared to PA11 due to poor interfacial adhesion between the dispersed phase and the continuous matrix, which leads to rapid initiation and crack growth $[9,13,14]$.

In our previous work [15], glycidyl methacrylate grafted ethylene- $n$-octene copolymer (GEOC) was used as an effective compatibilizer for PA11/PPO 80/20 blend. The SEM results showed that PPO formed the continuous phase, though it was a minority component of the blend. The morphology of the blends changed with increasing GEOC content from 5 to $15 \mathrm{wt} \%$ from a droplet-matrix structure to a co-continuous structure in which both PA11 and PPO phases were continuous. Moreover, the blend with co-continuous structure was characterized by better mechanical properties than the blends with droplet-matrix morphology.

Therefore, based on our previous experience [16-18], it was expected that the functionalized silica would improve the compatibility of PA11 with PPO and enhance the thermal and mechanical properties of the blends. Functional groups (e.g. amine, epoxy) from modified silica can react with the functional groups (amine, $\mathrm{OH}$ ) on PA11, which generates covalent bonds between them. Therefore, modified silica acts as a chain extender and crosslinking agent for PA11. The interfacial adhesion between PA11/PPO can be improved. According to the best of our knowledge, the influence of functionalized spherical silica on the morphology and properties of PA11/PPO blends has not been studied yet.

In this work, PA11/PPO 80/20 blends with 1,3 or $5 \mathrm{wt} \%$ of amine-functionalized silica $\left(\mathrm{A}-\mathrm{SiO}_{2}\right)$ were prepared by melt compounding, using a co-rotating twin screw extruder. Morphological and mechanical properties were analyzed, using several techniques, i.e., scanning electron microscopy (SEM), dynamic-mechanical thermal analysis (DMTA) and differential scanning calorimetry (DSC). Moreover, the effect of $\mathrm{A}-\mathrm{SiO}_{2}$ content on thermal, tensile, flexural and impact properties of PA11/PPO 80/20 blend was studied.

\section{EXPERIMENTAL PART}

\section{Materials and processing}

Bio-based semicrystalline polyamide 11 (PA11) used in this study was provided by Arkema (France) under the trade name Rilsan, with the melt flow rate of $22 \mathrm{~g} / 10 \mathrm{~min}$ (at $235^{\circ} \mathrm{C}$ and $10 \mathrm{~kg}$ ). Amorphous poly(2,6-dimethyl1,4-phenylene oxide) (PPO) was supplied by Sabic GE Plastics Co. USA under the trade name Noryl V0150B, with the melt flow rate of $4 \mathrm{~g} / 10 \mathrm{~min}\left(\right.$ at $300^{\circ} \mathrm{C}$ and $5 \mathrm{~kg}$ ). Modified silica having $0.35 \mathrm{wt} \%$ of amine functional groups $\left(\mathrm{A}-\mathrm{SiO}_{2}\right)$, with an average diameter of $30 \mathrm{~nm}$ and specific surface area of $274.4 \mathrm{~m}^{2} / \mathrm{g}$, was prepared by the reported sol-gel method $[19,20]$ and used as a compatibilizer at a concentration of 1,3 and $5 \mathrm{wt}$. \%.

\section{Silica preparation}

Silica having amine functional groups $\left(\mathrm{A}-\mathrm{SiO}_{2}\right)$ was synthesized using a procedure published elsewhere $[19,20]$. Briefly, tetraethoxysilane (TES 28, Wacker Chemie, Germany) was added as a precursor to ethyl alcohol, aqueous ammonia and distilled water mixture, and stirred for 2 hours. When the $\mathrm{pH}$ of the reaction mixture was in the range of 7.5-10.8, g-aminopropyltriethoxysilane (Momentive Performance Materials, USA) was added dropwise and stirring was continued for 1 hour. The silica sol was dried in an oven at $50-90^{\circ} \mathrm{C}$ for $2 \mathrm{~h}$ to obtain modified silica $\left(\mathrm{A}-\mathrm{SiO}_{2}\right)$.

\section{Composites compounding}

Before blending, PA11 and PPO were dried at $85^{\circ} \mathrm{C}$ under a vacuum for about $12 \mathrm{~h}$ to remove moisture. PA11, PPO and $\mathrm{A}-\mathrm{SiO}_{2}$ were melt mixed, using a twin screw extruder (ZE 25A x 51 D, KraussMaffei Berstorff, Germany) with co-rotating intermeshing screws ( $D=25 \mathrm{~mm}, L / D=51$ ) based on the reported method [21]. Separate gravimetric feeders were used for PA11, PPO and silica. The process was carried out at $190-250^{\circ} \mathrm{C}$, and a screw rotation speed was set to $200 \mathrm{rpm}$. The extruder was equipped with a highly efficient vacuum vent to remove any moisture traces or other volatile products formed during melt blending. After mixing, the material was extruded from the die with two cylindrical nozzles $4 \mathrm{~mm}$ in diameter, then quickly cooled in a water bath and cut into $4 \mathrm{~mm}$ pellets. The composites were injection molded at $230-245^{\circ} \mathrm{C}$ using an Arburg $420 \mathrm{M}$ single screw injection machine (Allrounder 1000-250, Germany) to obtain samples for SEM and mechanical tests. The mold temperature was $80^{\circ} \mathrm{C}$. 


\section{Testing methods}

\section{Modified silica characterization}

The particle size and the particle size distribution of the obtained sol were measured by photon correlation spectroscopy (PCS), using a Malvern apparatus (Zetasizer Nano ZS). The specific surface area of silica nanoparticles was measured by BET-N2 sorption method, using a Gemini 2370 V.302 apparatus. Kiejdahl method based on nitrogen content measurement was used to determine amine group content. The morphology of modified silica was studied, recording images on a Jeol JSM-6490LV scanning electron microscope (Japan), operating at an accelerating voltage $15 \mathrm{kV}$. A spherical shape and uniform size of obtained $\mathrm{A}-\mathrm{SiO}_{2}$ particles can be observed in SEM micrograph presented in Figure 1.

\section{Composites characterization}

The tensile and flexural properties were determined according to ISO 527 and ISO 178, respectively. An Instron 5500R universal testing machine (UK) was used. The crosshead speed for tensile and flexural tests was 5 and $2 \mathrm{~mm} / \mathrm{min}$, respectively. The gage length for tensile tests was $50 \mathrm{~mm}$. Notched Charpy impact tests (ISO 179) were performed, using a Zwick impact tester. All tests were carried out at room temperature. Five measurements were done for each data point in all mechanical property tests. A Rheometrics RDS 2 (USA) dynamic mechanical analyzer was used to determine the dynamic mechanical properties. Prepared by injection molding rectangular samples of $38 \times 10 \times 2 \mathrm{~mm}$ were tested in the torsion mode in the temperature range from -150 to $200^{\circ} \mathrm{C}$ and a heating rate of $3^{\circ} \mathrm{C} / \mathrm{min}$. The frequency was fixed at $1 \mathrm{~Hz}$ with an applied strain of $0.1 \%$. The gel content was determined as follows: $250 \mathrm{mg}$ sample was dissolved in $50 \mathrm{ml}$ of chloroform at room temperature. The soluble part was removed by filtration until deposition could be detected in chloroform solution by adding excess of acetone. Then the insoluble component was dried and then dissolved in $50 \mathrm{ml}$ of nitric acid at room temperature for $4 \mathrm{~h}$. The soluble part was removed by filtration until no deposition could be detected in nitric acid solution by adding excess of alcohol. The insoluble gel was washed well with alcohol, dried, and weighted. The percentage of insoluble gel was defined as the gel content. A Joel JSM 6100 scanning electron microscope (Japan) was used to determine the morphology and distribution of the silica particles in the PA11/PPO 80/20 blend. Prior to SEM observation, the samples were etched for 5 hours at room temperature with nitric acid or chloroform, a good solvent for PA11 and PPO, respectively. After etching, the samples were cleaned in distilled water and acetone and then dried. The impact fracture surfaces were coated with a thin gold film to avoid charging and to increase image contrast. Differential scanning calorimetry was performed with a Mettler-Toledo (Switzerland) device. The samples were heated from 25 to $300^{\circ} \mathrm{C}$ at a heating rate of $10^{\circ} \mathrm{C} / \mathrm{min}$ under argon flow. Then the samples were held at $300^{\circ} \mathrm{C}$ for $5 \mathrm{~min}$ to ensure an identical thermal history. The glass transition temperature $\left(T_{0}\right)$, melting temperature $\left(T_{m}\right)$, melting enthalpy $\left(\Delta H_{m}\right)$ and crystallization temperature $\left(T_{c}\right)$ were measured. A standard melting enthalpy $\left(\Delta H_{m}^{\circ}\right)$ of $189 \mathrm{~J} / \mathrm{g}$ for $100 \%$ crystalline PA11 [22] was used to calculate the degree of crystallinity $\left(X_{c}\right)$, as defined by Equation 1:

$$
X_{c}=\left(\frac{\Delta H_{m}}{w_{\mathrm{PA} 11} \Delta H_{m}^{\circ}}\right) \cdot 100
$$

where: $\Delta H_{m}$ is the enthalpy of fusion for composites and $w_{\text {PA11 }}$ is the weight fraction of PA11 in the sample. Thermogravimetric analysis was performed, using a TGA/SDTA 851 e (Mettler-Toledo, Switzerland). Samples of approximately $20 \mathrm{mg}$ were placed in alumina crucibles. An empty alumina crucible was used as reference. The composites were heated from room temperature to $700^{\circ} \mathrm{C}$ in a $60 \mathrm{~mL} / \mathrm{min}$ air flow at heating rates of 5, 10 and $20^{\circ} \mathrm{C} / \mathrm{min}$. Continuous recordings of sample temperature, sample weight, its first derivative and heat flow were performed.

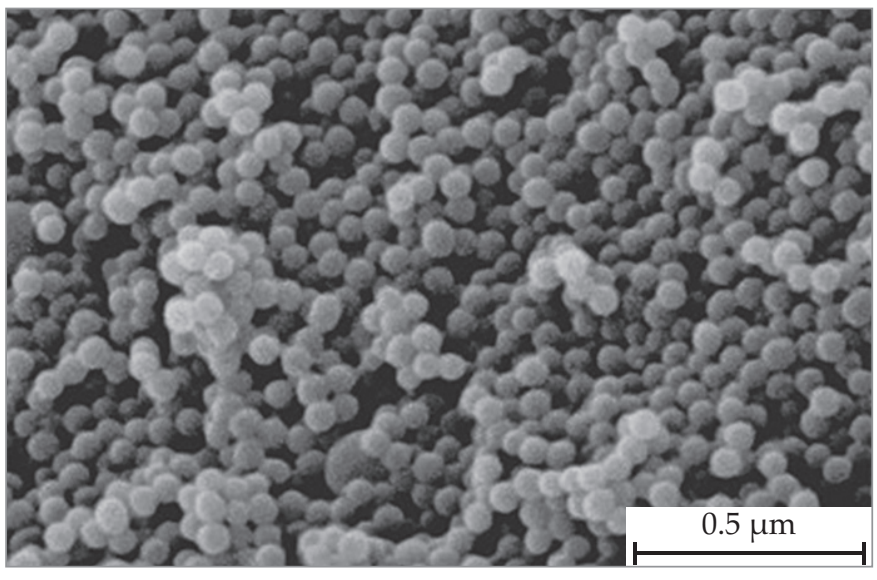

Fig. 1. SEM micrograph of $\mathrm{A}-\mathrm{SiO}_{2}$ particles with an average size of $30 \mathrm{~nm}$

\section{RESULTS AND DISCUSSION}

\section{Efect of modified silica on mechanical properties}

The tensile properties, as well as impact strength of PA11, PPO and PA11/PPO/A-SiO ${ }_{2}$ composites are reported in Table 1. PA11 is a relatively tough material, showing yielding behavior in stress-strain curve [15]. On the contrary, PPO is a brittle high-strength polymer (Fig. 2). It is clear from Fig. 3 and Table 1 that the mechanical behavior of PA11/PPO blend and its composites with modified silica is considerably different from that of pristine polymer components. Indeed, the addition of $20 \mathrm{wt} \%$ of PPO 
Table 1. Properties of PA11, PPO and PA11/PPO/A-SiO 2 composites

\begin{tabular}{|c|c|c|c|c|c|c|}
\hline Sample & $\begin{array}{l}\text { Tensile } \\
\text { modulus } \\
\mathrm{MPa}\end{array}$ & $\begin{array}{l}\text { Flexural } \\
\text { modulus } \\
\mathrm{MPa}\end{array}$ & $\begin{array}{l}\text { Tensile } \\
\text { strength } \\
\mathrm{MPa}\end{array}$ & $\begin{array}{c}\text { Flexural } \\
\text { strength } \\
\mathrm{MPa}\end{array}$ & $\begin{array}{c}\text { Elongation } \\
\text { at break } \\
\mathrm{MPa} \\
\end{array}$ & $\begin{array}{l}\text { Notched Impact } \\
\text { strength } \\
\mathrm{kJ} / \mathrm{m}^{2}\end{array}$ \\
\hline PA11 & $1240 \pm 55$ & $1180 \pm 35$ & $42 \pm 1$ & $45 \pm 1$ & $299 \pm 9$ & $15 \pm 0.6$ \\
\hline PPO & $2515 \pm 49$ & $2250 \pm 30$ & $70 \pm 1$ & $58 \pm 1$ & $10 \pm 1$ & $6 \pm 1.2$ \\
\hline PPO/PA11 & $1290 \pm 40$ & $1215 \pm 30$ & $42 \pm 1$ & $45 \pm 1$ & $245 \pm 7$ & $9 \pm 0.5$ \\
\hline $1 \mathrm{wt} \% \mathrm{SiO}_{2}$ & $3080 \pm 58$ & $1410 \pm 7$ & $47 \pm 1$ & $54 \pm 1$ & $74 \pm 3$ & $17 \pm 0.8$ \\
\hline $3 \mathrm{wt} \% \mathrm{~A}-\mathrm{SiO}_{2}$ & $3365 \pm 60$ & $1440 \pm 12$ & $47 \pm 1$ & $55 \pm 1$ & $115 \pm 3$ & $19 \pm 0.6$ \\
\hline $5 \mathrm{wt} \% \mathrm{~A}-\mathrm{SiO}_{2}$ & $3350 \pm 78$ & $1520 \pm 8$ & $48 \pm 1$ & $58 \pm 1$ & $64 \pm 1$ & $12 \pm 0.3$ \\
\hline
\end{tabular}

to PA11 decreased elongation at break. Moreover, impact strength decreased from 15 to $9 \mathrm{~kJ} / \mathrm{m}^{2}$. This is because PPO is an amorphous polymer and PA11 is a crystalline polymer, which are thermodynamically immiscible. As expected modules, tensile and flexural strengths of the the blend were lower than pristine PPO, and higher than pristine PA11. The dispersion state of silica particles as well as their interaction with polymer matrix can influence the properties of composites. It is possible to notice the A-Si- $\mathrm{O}_{2}$ reinforcing effect on both polymeric matrices. Tensile and flexural modulus as well as tensile and flexural strengths increased as a function of silica and this fact, denoted a good dispersion of $\mathrm{A}-\mathrm{SiO}_{2}$ particles in the blend, was also confirmed by SEM image of Fig. 8c. However, the effect of silica concentration was moderate, suggesting that all composites exhibited similar state of dispersion of $\mathrm{A}-\mathrm{SiO}_{2}$. It is well known that silica finely dispersed in the polymer matrix with strong interaction between silica nanoparticles and the polymer induces the strengthening effect [16-18].

Generally, a small amount of nanofillers increases impact strength of filled polymers. However, a decrease in impact strength can be observed at higher nanofiller loading. The improvement can be stronger when functionalized nanoparticles are used due to the chemical reactions between functional groups of the nanofiller and the polymer matrix [17, 23-25]. The incorporation of $\mathrm{A}-\mathrm{SiO}_{2}$ results in a remarkable increase in impact

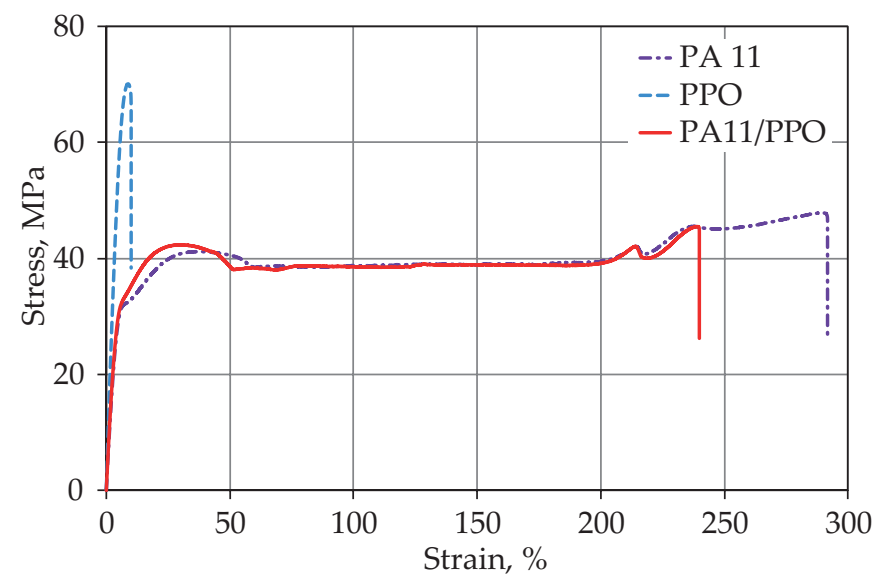

Fig. 2. Stress-strain curves of PA11, PPO and PA11/PPO 80/20 blend strength, due to the compatibilizing effect caused by reaction between amine group of silica and carboxyl group of PA11. However, increasing silica content to $5 \mathrm{wt} \% \mathrm{~A}-\mathrm{SiO}_{2}$ leads to a decrease in impact strength (to $\left.12 \mathrm{~kJ} / \mathrm{m}^{2}\right)$, though, it is still $33 \%$ higher compared to the blend without silica. This phenomenon is most probably caused by the aggregation of silica and changes in the morphology depending on silica content (Figs. 8, 9). The aggregates formed at higher $\mathrm{A}-\mathrm{SiO}_{2}$ content behave like defects in the composites, inducing stress concentration and thus reducing the impact strength of the composites [26]. These results confirm the behavior observed in SEM.

As expected, addition of silica decreases the elongation at break of the blend as often reported when nanoparticles were used [7, 27-28].Nevertheless, it is noteworthy that also at higher silica content significant elongation at break was achieved $\left(115 \%\right.$ at $3 \mathrm{wt} \% \mathrm{~A}-\mathrm{SiO}_{2}$, and $64 \%$ at $5 \mathrm{wt} \% \mathrm{~A}-\mathrm{SiO}_{2}$ ). Small decrease in ductility can be due to both effects of partial plasticization of the particles and good miscibility between $\mathrm{A}-\mathrm{SiO}_{2}$ and PA11 that not completely decrease the chain mobility $[29,30]$.

\section{Efect of modified silica on dynamic mechanical properties}

The storage modulus $\left(G^{\prime}\right)$ and loss modulus $\left(G^{\prime \prime}\right)$ of PA11, PPO and PA11/PPO 80/20 blend as a function of temperature are shown in Figures $4 \mathrm{a}$ and $4 \mathrm{~b}$, respectively.

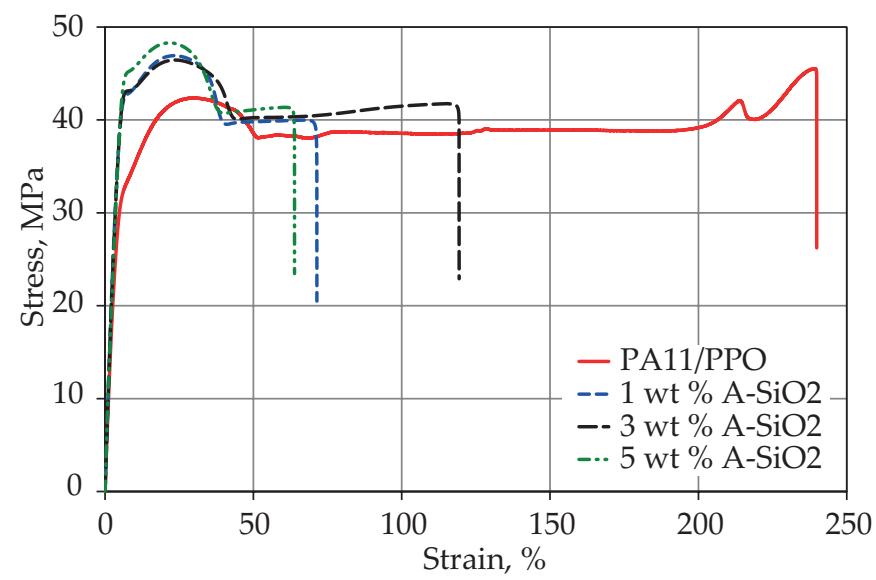

Fig. 3. Stress-strain curves of $\mathrm{PA11} / \mathrm{PPO} / \mathrm{A}-\mathrm{SiO}_{2}$ composites 
Table 2. Storage modulus of PA11, PPO, and PA11/PPO/A-Si-O ${ }_{2}$ composites

\begin{tabular}{|c|c|c|c|c|}
\hline \multirow{2}{*}{ Samples } & \multicolumn{4}{|c|}{$G^{\prime}, \mathrm{MPa}$} \\
\hline & $\mathrm{T}=-140^{\circ} \mathrm{C}$ & $\mathrm{T}=-70^{\circ} \mathrm{C}$ & $\mathrm{T}=23^{\circ} \mathrm{C}$ & $\mathrm{T}=50^{\circ} \mathrm{C}$ \\
\hline PA 11 & 2020 & 1050 & 695 & 395 \\
\hline $\mathrm{PPO}$ & 1680 & 1520 & 1400 & 1360 \\
\hline PPO/PA 11 & 1960 & 1200 & 840 & 495 \\
\hline 1 wt $\% \mathrm{~A}-\mathrm{SiO}_{2}$ & 1710 & 1030 & 735 & 471 \\
\hline $3 \mathrm{wt} \% \mathrm{~A}-\mathrm{SiO}_{2}$ & 2130 & 1230 & 890 & 547 \\
\hline 5 wt $\% \mathrm{~A}-\mathrm{SiO}_{2}$ & 2140 & 1250 & 930 & 584 \\
\hline
\end{tabular}

A typical behavior of the storage modulus with three confined regions, the glassy region, the glass transition and the rubbery region, corresponding to the chain segments relaxation of PA11 and PPO, respectively, was observed for the polymers and the blend. As shown in Fig. 4a, three rapid reductions of storage modulus corresponding to the chain segments relaxation were observed in the PA11. As expected PA11/PPO blend showed lower storage modulus than PPO. However, the blend had higher storage modulus in the glassy and glass transition regions, and lower in the rubbery region as compared to neat PA11 (see Tab. 2).

Figure $4 \mathrm{~b}$ shows the loss modulus $\left(G^{\prime \prime}\right)$ as a function of temperature for PA11, PPO and PA11/PPO blend. The peaks on the curve correspond to $\mathrm{a}, \beta$ and g relaxations of the polymers. Table 3 presents the $T_{\alpha^{\prime}} T_{\beta}$ and $T_{\gamma}$ values of the samples. The $\beta$ and $\gamma$ transitions of PPO were at -18 and $-118^{\circ} \mathrm{C}$, respectively. The $\alpha$ relaxation corresponds to the glass transition temperature $\left(T_{g}\right)$ [15]. The $T_{\alpha}$ of PA11 in the PA11/PPO blend is $50^{\circ} \mathrm{C}$. However, the glass transition temperature of the blend was $2^{\circ} \mathrm{C}$ lower compared to PA11. The $T_{g}$ of PPO could not be detected since it was too close to the melting point of PA11 in the temperature range from 170 to $195^{\circ} \mathrm{C}$.

The $\beta$ relaxation was observed as a weak maximum in loss modulus for PPO. On the contrary, PA11 and PA11/PPO blend had a clear single $\beta$ relaxation peak. It was reported that the $\beta$ relaxation resulted from motions of amide polar groups of polyamide in the interfacial

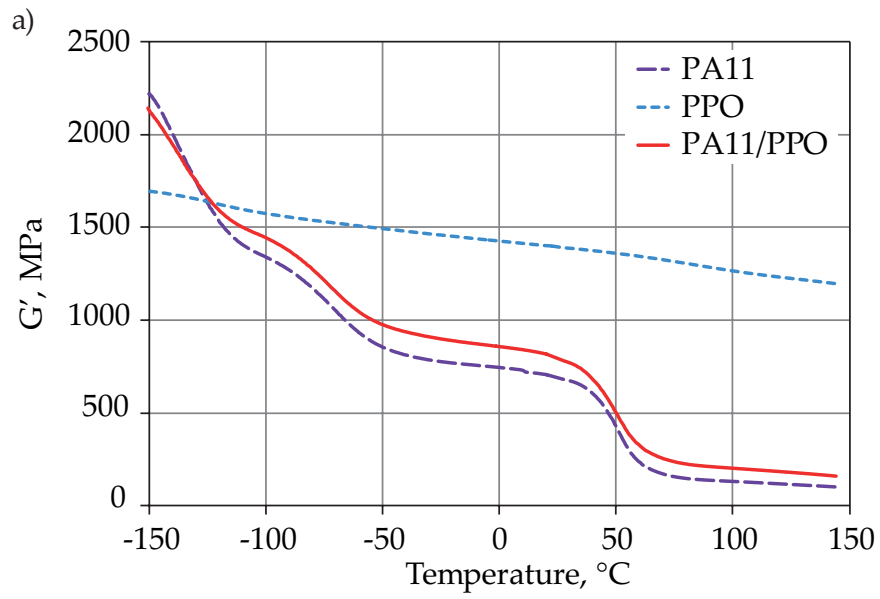

region and was attributed to the glass transition [31]. The $\beta$ relaxation temperature of the blend was $2^{\circ} \mathrm{C}$ and $53^{\circ} \mathrm{C}$ lower compared to PA11 and PPO, respectively. The $\gamma$ relaxation is associated with a single relaxation process, predominantly of amorphous origin. The $\gamma$ relaxation appeared as a maximum at $-118^{\circ} \mathrm{C}$ for $\mathrm{PPO}$ and at $-140^{\circ} \mathrm{C}$ for PA11 (Fig. 4b, Table 4), with a corresponding decrease in storage modulus (Fig. 4a). The $T_{\gamma}$ of PA11/PPO had the same value as PA11and was $22^{\circ} \mathrm{C}$ lower compared to PPO.

The dependence of storage modulus for PA11/ PPO/A$\mathrm{SiO}_{2}$ composites on the temperature is shown in Figure 5 a. At low temperature, no vibration, rotation and translation occur because molecules have not enough energy. Therefore, the storage modulus curve is smooth. At high temperature, molecules have enough energy to vibrate, rotate, and translate resulting in the decrease of storage modulus. It is clear from Fig. 5a and Table 3 that the influence of $\mathrm{A}-\mathrm{SiO}_{2}$ on the storage modulus of the blend is significant. However, adding $1 \mathrm{wt} \% \mathrm{~A}-\mathrm{SiO}_{2}$ results in lower storage modulus compared to the PA11/PPO blend. The slight decrease in stiffness can be caused by both the effects of partial plasticization of the particles and the good miscibility between $\mathrm{A}-\mathrm{SiO}_{2}$ and PA11, which do not completely reduce the mobility of the chain $[29,30]$.

The effect of the modified silica vary to a similar extent as the tensile modulus, as shown in Table 1. These results correspond to the morphology change observed with SEM micrographs (Figs. 7-9). The amine group in

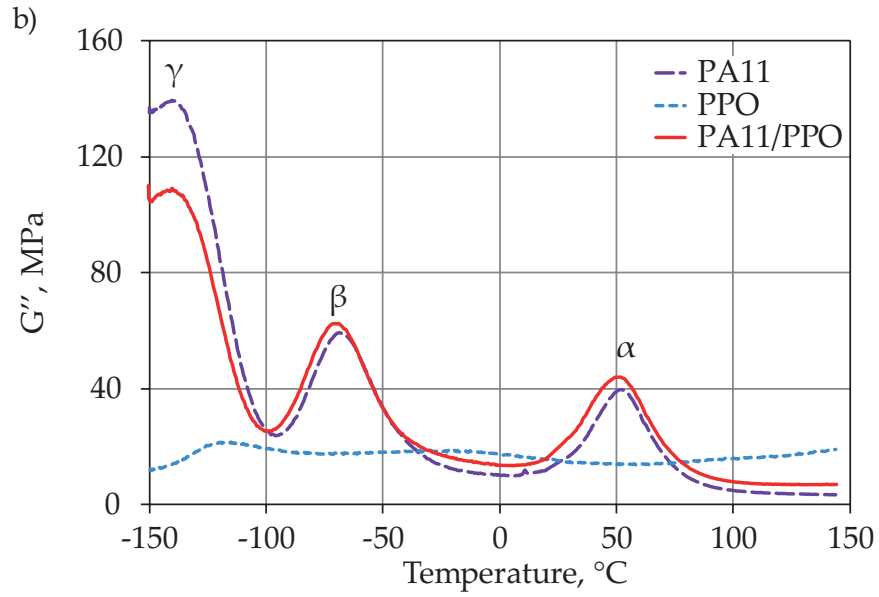

Fig. 4. Dynamic mechanical properties of PA11, PPO and PA11/PPPO 80/20 blend as a function of temperature: a) storage modulus $\left(G^{\prime}\right)$ and b) loss modulus ( $\left.G^{\prime \prime}\right)$ 
$\mathrm{T}$ a b 1 e 3. DMTA data for PA11, PPO and PA11/PPO/A-SiO ${ }_{2}$ composites

\begin{tabular}{|c|c|c|c|c|c|c|}
\hline \multirow[t]{2}{*}{ Samples } & \multicolumn{3}{|c|}{ Temperature, ${ }^{\circ} \mathrm{C}$} & \multicolumn{3}{|c|}{ Peak intensity, $\mathrm{MPa}$} \\
\hline & $\alpha$ & $\beta$ & $\Gamma$ & A & $\beta$ & $\gamma$ \\
\hline PA 11 & 52 & -69 & -140 & 39.7 & 59.4 & 139 \\
\hline $\mathrm{PPO}$ & - & -18 & -118 & - & 13.4 & 12 \\
\hline PA 11/PPO & 50 & -71 & -140 & 43.8 & 62.3 & 109 \\
\hline $1 \mathrm{wt} \% \mathrm{~A}-\mathrm{SiO}_{2}$ & 53 & -68 & -138 & 41.0 & 53.2 & 97 \\
\hline $3 \mathrm{wt} \% \mathrm{~A}-\mathrm{SiO}_{2}$ & 53 & -69 & -139 & 47.7 & 59.3 & 114 \\
\hline $5 \mathrm{wt} \% \mathrm{~A}-\mathrm{SiO}_{2}$ & 53 & -70 & -140 & 52.6 & 64.1 & 118 \\
\hline
\end{tabular}

a)

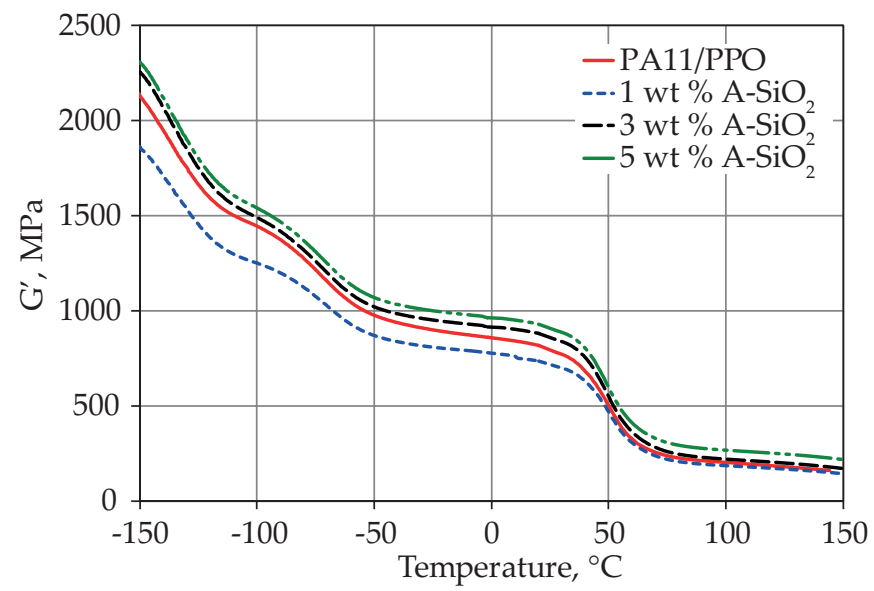

b)

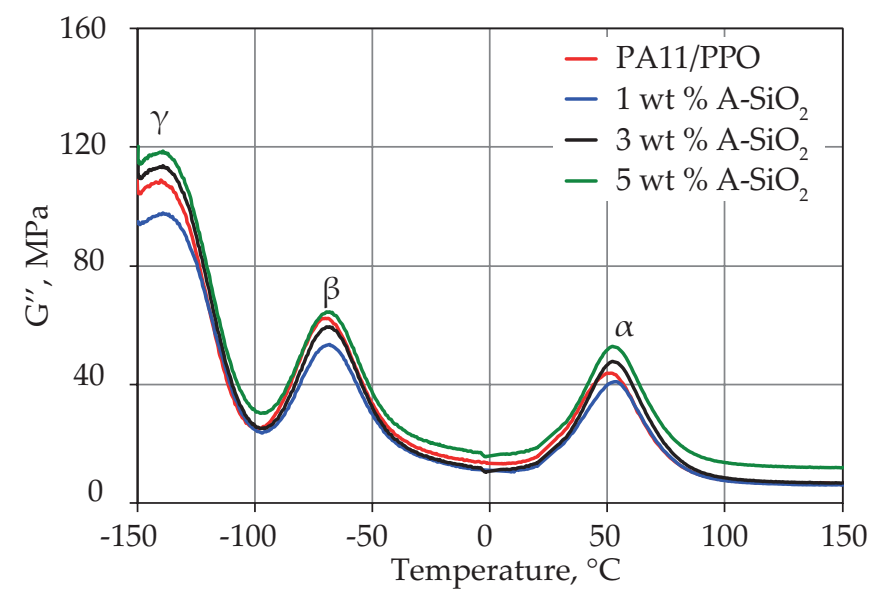

Fig. 5. Dynamic mechanical properties of PA11/PPO/A-Si-O $\mathrm{O}_{2}$ composites as a function of temperature: (a) storage modulus $\left(G^{\prime}\right)$ and (b) loss modulus $\left(G^{\prime \prime}\right)$

$\mathrm{A}-\mathrm{SiO}_{2}$ strongly interacts with the carboxyl group in PA11, resulting in a strong confinement effect of $\mathrm{A}-\mathrm{SiO}_{2}$ to PA11 chains. Similar results for the dynamic mechanical properties of functionalized carbon nanotubes filled PPO/PA6 blends have been reported in literature [32].

Figure $5 \mathrm{~b}$ shows the loss modulus $\left(G^{\prime \prime}\right)$ as a function of temperature for PA11/PPO composites differing in silica content. Table 3 lists $T_{\alpha^{\prime}} T_{\beta}$ and $T_{\gamma}$ values of the composites. From Figure $5 b$ it can be seen that the addition of silica resulted in a higher glass transition temperature of the PA11 phase in the composites caused by the strong link. This indicates improvement in the compatibility of the composites containing amine-functionalized silica. However, the effect of silica content on $T_{\alpha}$ of PA11/PPO blend is moderate. Moreover, the intensity of a relaxation peaks observed in $G^{\prime \prime}$ curves increased with $\mathrm{A}-\mathrm{SiO}_{2}$ loading, which indicates improved stiffness. Furthermore, the addition of silica resulted in no significant change of the $T_{\beta}$ and $T_{\gamma}$ temperatures in the composites. However, incorporation of $1 \mathrm{wt} \% \mathrm{~A}-\mathrm{SiO}_{2}$ into the blend increased $\beta$ and $g$ relaxation temperatures by 3 and $2{ }^{\circ} \mathrm{C}$, respectively. Moreover, the effect of $\mathrm{A}-\mathrm{SiO}_{2}$ on the intensity of $\beta$ and $\gamma$ relaxation peaks varied with similar extent as the tensile modulus, as can be seen in Table 1.

\section{Morphology}

It is well known that the morphology control of the respective phases is a key factor in achieving the desired properties [33, 34]. The Fig. 6 briefly shows the in situ compatibilization of PA11/PPO blend, where part of $\mathrm{A}-\mathrm{SiO}_{2}$ particles formed graft copolymer with PA11, which can efficiently control the phase morphology of the blend during melt mixing. The amount of in situ formed<smiles>NCC1C(CN)C(CN)(CN)C1CN</smiles>

$\mathrm{A}-\mathrm{SiO}_{2}$<smiles>CCC(=O)O</smiles>

PA11<smiles>CC(=O)NCC1C(CN)CC(CN)C1CN</smiles>

$\mathrm{PA} 11-g-\mathrm{A}-\mathrm{SiO}_{2}$

Fig. 6. Schematic description of the in-situ compatibilization 
a)

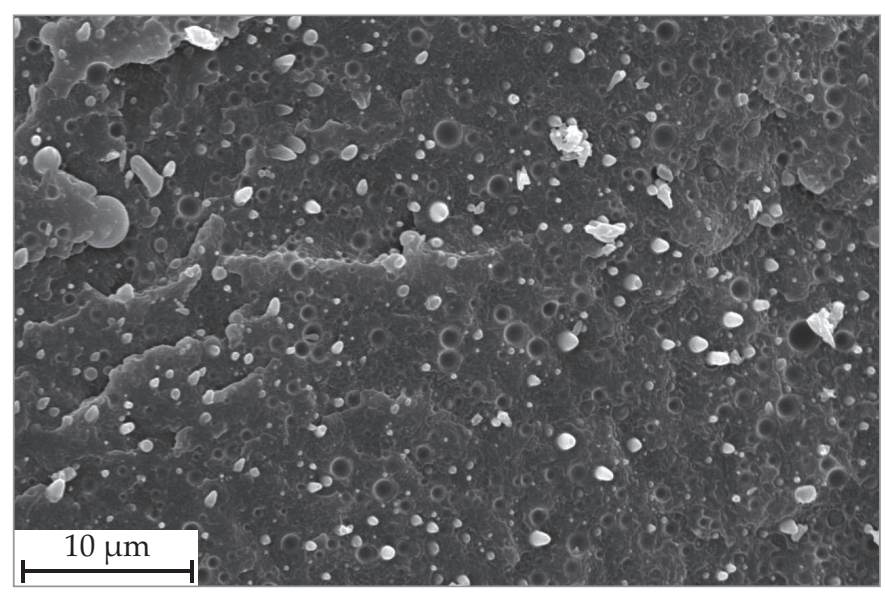

b)

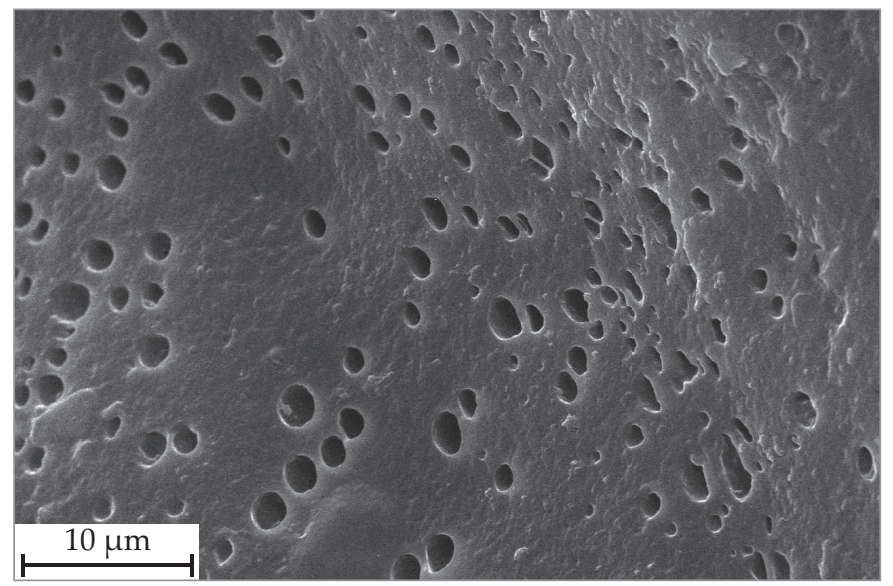

Fig. 7. The cross-section of the PA11/PPO 80/20 blend: a) not extracted, b) extracted with nitric acid; all images were reported at scales of $10 \mu \mathrm{m}$

PA11- $\mathrm{g}-\mathrm{A}-\mathrm{SiO}_{2}$ was calculated by the gel content tests. The samples were successively extracted by chloroform and then by nitric acid. The residue, insoluble in both solvents, was considered as a mixture of $\mathrm{A}-\mathrm{SiO}_{2}$ and $\mathrm{A}-\mathrm{SiO}_{2}$ grafted PA11. As presented in Table 4, with increasing $\mathrm{A}-\mathrm{SiO}_{2}$ content, the amount of grafted PA11 increases, which indicates a higher melt viscosity of PA11 phase and confirms the reaction between $\mathrm{A}-\mathrm{SiO}_{2}$ and PA11.

a)

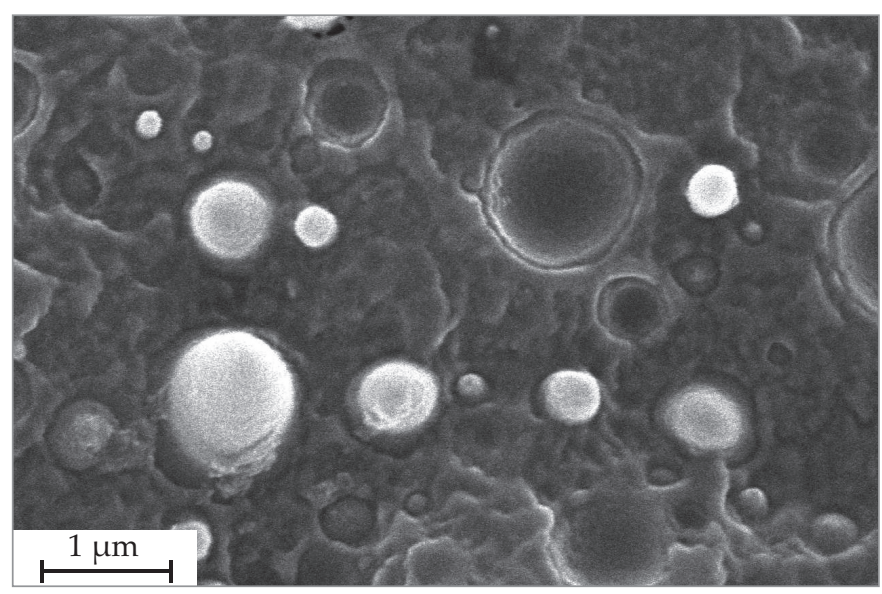

c)

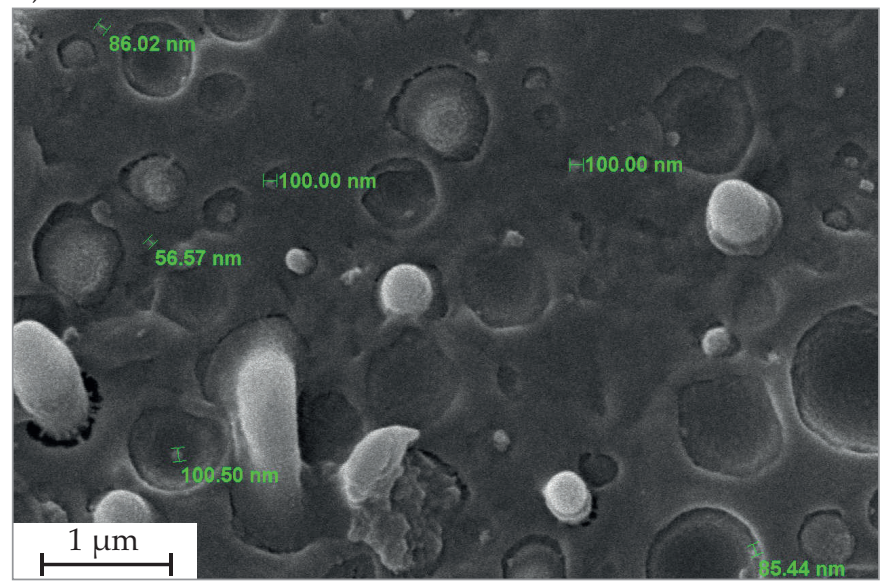

$\mathrm{T}$ a b 1 e 4 . Effect of $\mathrm{A}-\mathrm{SiO}_{2}$ on the gel content in PA11/PPO/A$-\mathrm{SiO}_{2}$ composites

\begin{tabular}{c|c}
\hline $\mathrm{A}_{-} \mathrm{SiO}_{2}, \mathrm{wt} \%$ & Gel content, \% \\
\hline 0 & 0 \\
1 & 29 \\
3 & 42 \\
5 & 48 \\
\hline
\end{tabular}

b)

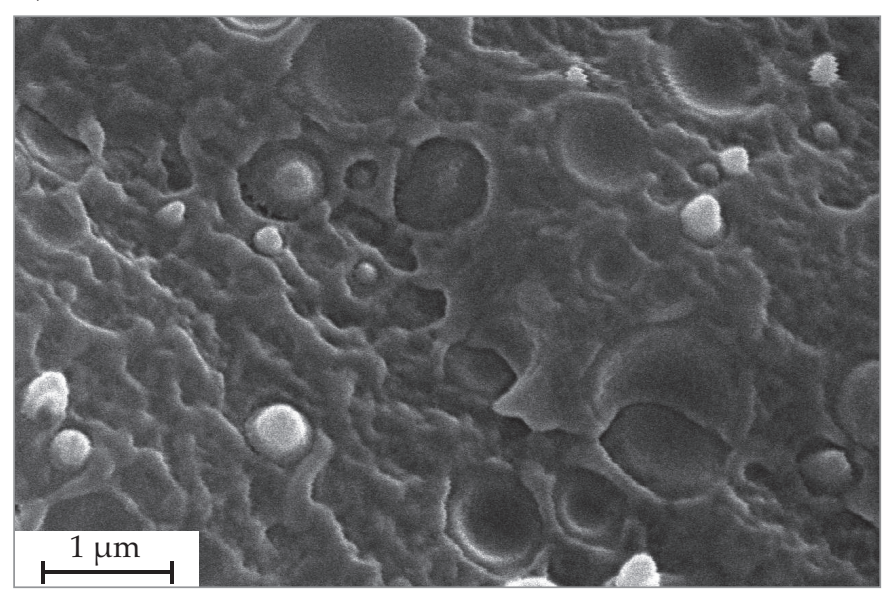

d)

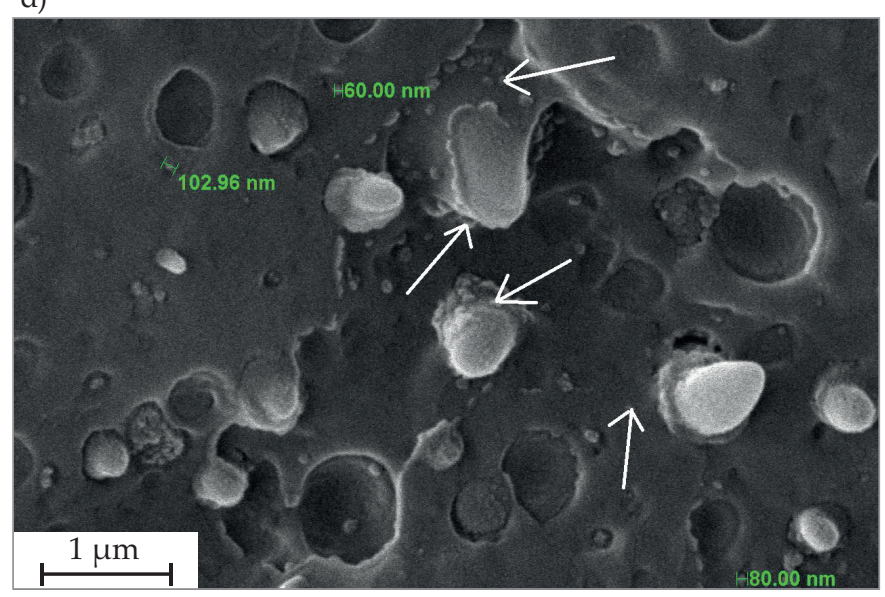

Fig. 8. The cross-section of the PA11/PPO 80/20 without extraction containing different amounts of silica: a) 0 wt $\%$ A-SiO ${ }^{\prime}$ b) $1 \mathrm{wt} \% \mathrm{~A}-\mathrm{SiO}_{2}$, c) $3 \mathrm{wt} \% \mathrm{~A}-\mathrm{SiO}_{2}$, d) $5 \mathrm{wt} \% \mathrm{~A}-\mathrm{SiO}_{2}$; arrows $-\mathrm{A}-\mathrm{SiO}_{2}$; all images were reported at scales of $1 \mu \mathrm{m}$ 
a)

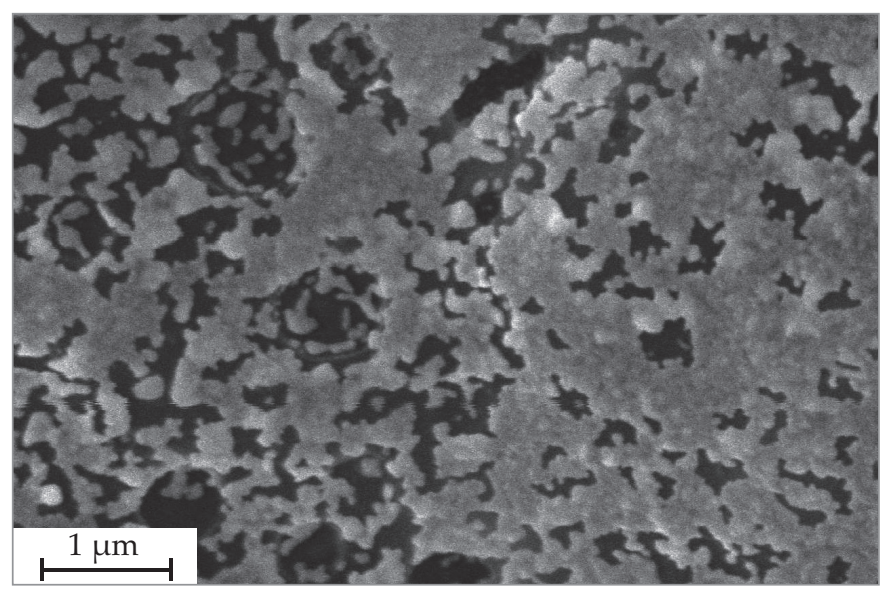

b)

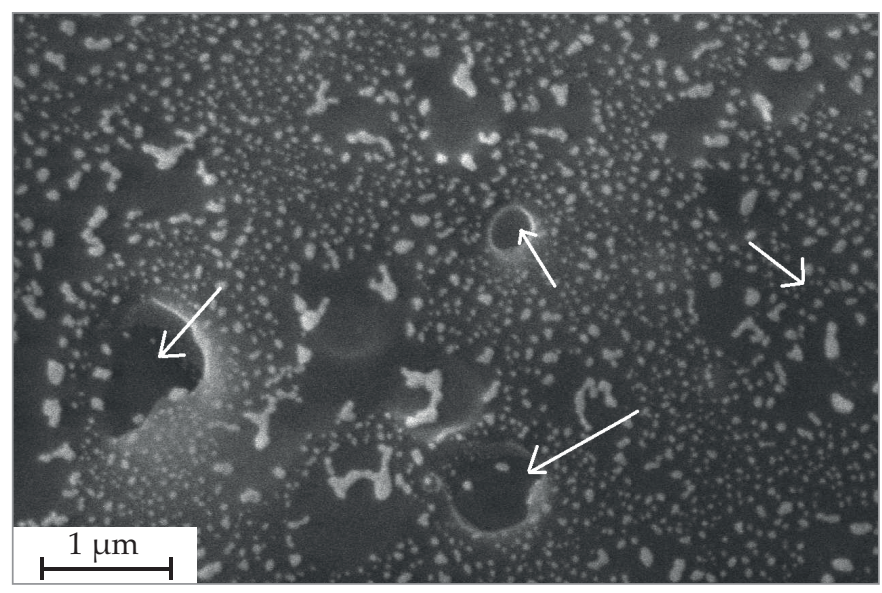

c)

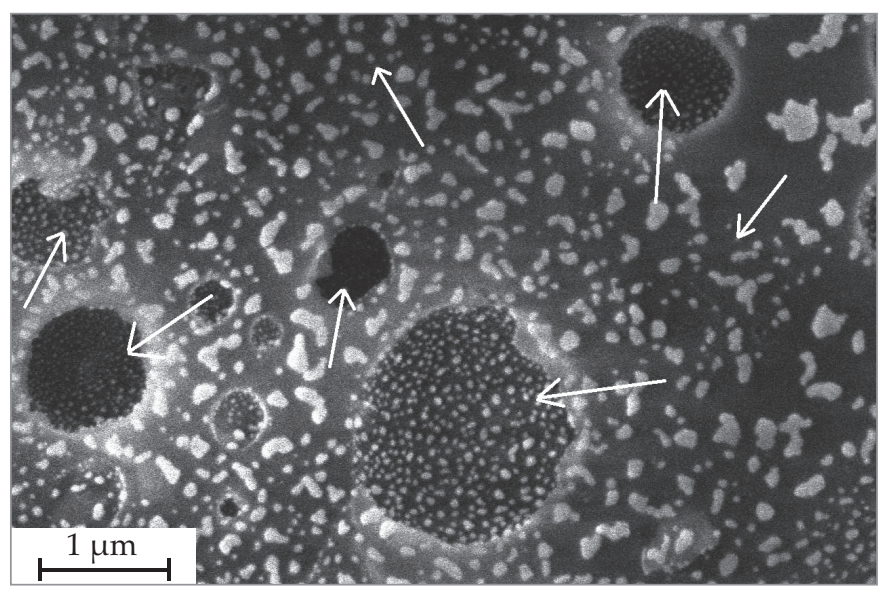

d)

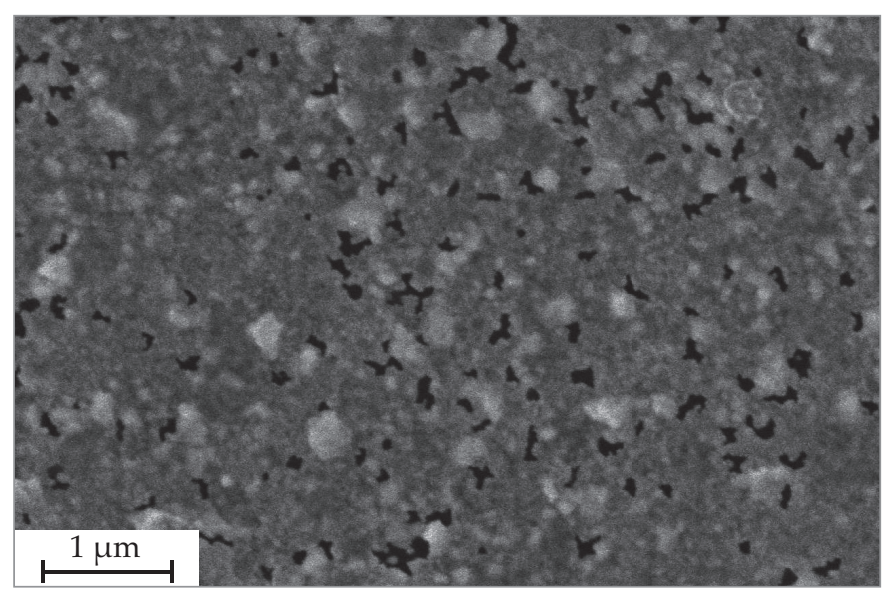

e)

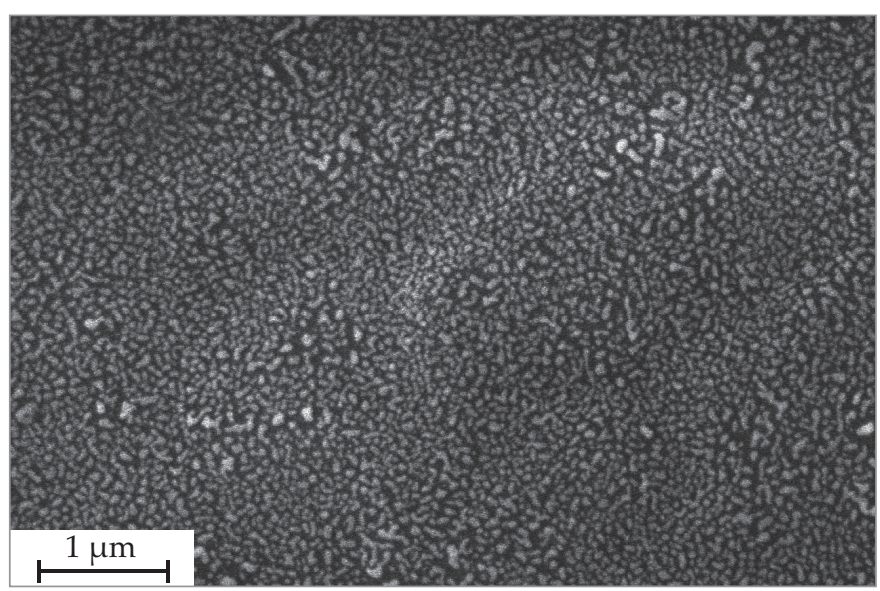

f)

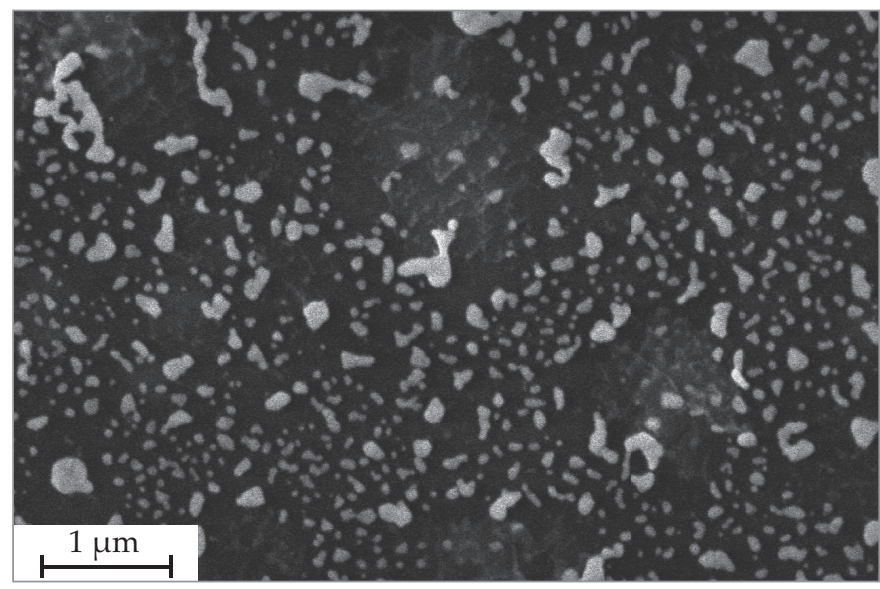

Fig. 9. The cross-section of the PA11/PPO 80/20 containing different amounts of silica extracted with chloroform: a) 1 wt $\%$ A-SiO ${ }^{\prime}$ b) $3 \mathrm{wt} \%{\mathrm{~A}-\mathrm{SiO}_{2}}$, $) 5 \mathrm{wt} \% \mathrm{~A}-\mathrm{SiO}_{2}$, and extracted with nitric acid: d) $1 \mathrm{wt} \% \mathrm{~A}-\mathrm{SiO}_{2}$, e) $3 \mathrm{wt} \% \mathrm{~A}-\mathrm{SiO}_{2}$, f) $5 \mathrm{wt} \% \mathrm{~A}-\mathrm{SiO}$; arrows $\mathrm{A}-\mathrm{SiO}_{2}$; all images were reported at scales of $1 \mu \mathrm{m}$

PA11 and PPO are thermodynamically immiscible and the properties of the blend depend not only on the properties of each phase but also on the morphology and adhesion between the phases [13, 14]. SEM technique was used to investigate the distributed phase morphology in the blend. Figure 7 shows the cross-sections images of the PA11/PPO blend not extracted and extracted with nitric acid. In the blend matrix-droplet morphology was observed. It is clear from Figure $6 \mathrm{~b}$, that PPO forms the continuous phase (dark grey) and PA11 forms the dis- 
persed phase (black), in spite of the fact that the amount of PPO in the blend is minority component. A fine dispersion of the holes corresponding to the extracted PA11 phase can be observed, most of them are less than $0.2 \mu \mathrm{m}$.

Figure 8 shows the cross-sections morphology of samples containing different amounts of modified silica without extraction. PA11 appears in micrographs of not extracted samples as white regions, PPO as dark grey, and $\mathrm{A}-\mathrm{SiO}_{2}$ as white. Figure $8 \mathrm{a}$ is the reference sample without $\mathrm{A}-\mathrm{SiO}_{2}$ Big particles of PA11 and the holes left by them, as well as gaps around the dispersed phase when the sample was broken, can be seen. It is clear, that no deformation of the matrix occurred during the break resulting in poor adhesion at the interface. After addition of modified silica, both the size and shape of PA11 dispersed phase changed, and the fractured surfaces exhibited a larger deformation with increasing silica content which suggests better compatibility between PA11 and PPO (Figs. 8b-d). Homogenous and uniform dispersion could be observed for silica particles with very few aggregates. The size of the agglomerates was in the range of 57-100 nm (Fig. 7c). Modified silica was located in both phases and along the interface. The well dispersed $\mathrm{A}-\mathrm{SiO}_{2}$ in both phases is clearly visible in Fig. 8c. However, at higher content (5 wt \%) modified silica was distributed in both phases as well as along the interface (Fig. 8c-d) due to the reaction between $\mathrm{A}-\mathrm{SiO}_{2}$ and end group of PA11 (Fig. 6), which lowers the impact properties of the composite compared to the composites where $\mathrm{A}-\mathrm{SiO}_{2}$ is located mainly in PA11 phase. This is because a portion of loaded $\mathrm{A}-\mathrm{SiO}_{2}$ was dispersed in PPO phase since PA11 phase could not accommodate more $\mathrm{A}-\mathrm{SiO}_{2}$ particles. Similar trend of morphological changes was reported for PPS/PA66 (60/40) and PS/PA6 (10/90, 90/10, 50/50) blends with nanotubes [24, 33], as well as for PPO/PA6 (50/50) blend with organically modified clay [9].

To further investigation into dispersion of $\mathrm{A}-\mathrm{SiO}_{2}$ in PA11/PPO blend, the samples were etched with nitric acid (a good solvent for PA11) and chloroform (a good solvent for PPO) to obtain a clear image of each phase. Figs. 9a-c shows the evolution of morphology in composites etched with chloroform, in which PA11 appears as gray or white regions and PPO as black. On the contrary, Figs. 9d-e shows the cross section of the samples etched with nitric acid, in which PPO appears as gray or white regions and PA11 as black. It is clear from Fig. 9 that the size of both phases decreases in the presence of silica. However, with silica content of $5 \mathrm{wt} \%$, a slight increase in the size of both phases was observed, which indicates that $\mathrm{A}-\mathrm{SiO}_{2}$ particles are surrounded by PA11. Modified silica is expected to lead to the formation of a co-continuous morphology. Indeed, Figure $9 \mathrm{e}$ shows that at a content of $3 \mathrm{wt} \% \mathrm{~A}-\mathrm{SiO}_{2}$, both PA11 and PPO phases are continuous and they interpenetrate each other which results in increased impact strength and elongation. In addition, in Figure 9d, the phase inversion for the composite containing $5 \mathrm{wt} \%$ of $\mathrm{A}-\mathrm{SiO}_{2}$ could be seen, and the matrix- droplet morphology reappeared. Thus, PA11 represents the matrix phase, and PPO the dispersed phase. These results are consistent with the mechanical properties. Indeed, lower toughness and elongation at break were observed with 5 wt $\%$ silica content.

\section{Thermal stability}

The compatibility of polymer blends can also be investigated by their melting and crystallization behaviors based on DSC measurements. Moreover, inorganic nanofillers usually improve thermal stability of polymer composites, due to lower mobility of polymer chains and reduced diffusion of volatile degradation products [24]. Silica ability as a nucleating agent on polymers is well known $[18,35]$. Therefore, the selective localization of silica can be proved by investigating the crystallization behavior of $\mathrm{PA} 11 / \mathrm{PPO} / \mathrm{A}-\mathrm{SiO}_{2}$ composites. The thermal behavior of PA11, PPO, PA11/PPO blend and its composites with $\mathrm{A}-\mathrm{SiO}_{2}$ was investigated by DSC and TGA. Table 5 , summarizes the values of the glass transition temperature $\left(T_{q}\right)$, crystallization $\left(T_{c}\right)$, melting $\left(T_{m}\right)$ and decomposition temperatures, defined as the weight loss onset temperature $\left(T_{\text {onset }}\right)$ and the temperature at the maximum weight loss rate $\left(T_{\max }\right)$ for PA11, PPO and PA11/PPO blend with various contents of $\mathrm{A}-\mathrm{SiO}_{2}$ obtained through DSC and TGA analysis.

In PA11/PPO blend, $T_{q}$ of PPO phase was not affected by introducing $80 \mathrm{wt} \%$ PA11. However, a slight increase in the crystallization temperature and a decrease in the melting point and crystallinity corresponding to the PA11 phase were observed. This indicates that these two polymers are highly immiscible and the blend is incompatible $[36,37]$.

It is clear from Table 5 that the addition of $1 \mathrm{wt} \% \mathrm{~A}-\mathrm{SiO}_{2}$ slightly increased the glass transition temperature, melting temperature and crystallization temperature, due to nucleating effect. These findings are in good agreement with our previous study $[16,18,38]$. However, when the content of $\mathrm{A}-\mathrm{SiO}_{2}$ increased from 1 to $5 \mathrm{wt} \%$, the melting and crystallization of the $\mathrm{PPO} / \mathrm{PA} 11 / \mathrm{A}-\mathrm{SiO}_{2}$ composites shifted toward the higher values, suggesting the interaction between amine-functionalized silica particles and PA11. In addition, the degree of super-cooling, $T_{m}-T_{c}$ can be used to explain the crystallization behavior of the polymers [24, 25]. The lower value of $T_{m}-T_{c}$ proves that the induction time of polymer crystallization in the PA11/ PPO blend and in composites is lower than in PA11. These results are in agreement with the $\mathrm{T}_{c}$ discussed above. The slight reduction in the crystallinity of the composites is due to the increase in the viscosity [22]. It is possible also that $\mathrm{A}-\mathrm{SiO}_{2}$ acts as a compatibilizer, improving the $\mathrm{PPO}$ and PA11 miscibility and reducing the crystallinity of PA11. These findings are in good agreement with SEM and DMTA studies. It was reported that fumed silica in $\mathrm{HDPE} / \mathrm{SiO}_{2}$ nanocomposites enhanced crystallization rate on one hand and reduced the degree of crystallin- 
T a b 1 e 5. DSC and TGA data for PA11, PPO and PA11/PPO/A-SiO ${ }_{2}$ composites

\begin{tabular}{l|c|c|c|c|c|c|c}
\hline \multicolumn{1}{c|}{ Sample } & $T_{g^{\prime}}{ }^{\circ} \mathrm{C}$ & $T_{c^{\prime}}{ }^{\circ} \mathrm{C}$ & $T_{m^{\prime}}{ }^{\circ} \mathrm{C}$ & $T_{m}-T_{c^{\prime}}{ }^{\circ} \mathrm{C}$ & $T_{\text {onset }}{ }^{\circ} \mathrm{C}$ & $T_{\text {max }}{ }^{\circ} \mathrm{C}$ & $X_{c^{\prime}} \%$ \\
\hline PA11 & 40 & 156 & 188 & 32 & 421 & 456 & 16.6 \\
PPO & 215 & - & - & - & 457 & 472 & - \\
PA11/PPO & 215 & 160 & 186 & 26 & 423 & 455 & 12.1 \\
1 wt $\% \mathrm{~A}-S i O_{2}$ & 216 & 161 & 189 & 28 & 432 & 458 & 9.7 \\
3 wt $\% \mathrm{~A}-S i O_{2}$ & 217 & 161 & 189 & 28 & 431 & 458 & 7.6 \\
5 wt \% A-SiO 2 & 216 & 162 & 190 & 28 & 433 & 467 & 8.7 \\
\hline
\end{tabular}

$\mathrm{T}$ a b 1 e 6. TGA data from the dynamic runs in air of PA11, PPO and PA11/PPO blend differing in A-SiO ${ }_{2}$ content at heating rate of 5,10 and $20^{\circ} \mathrm{C} / \mathrm{min}$

\begin{tabular}{|c|c|c|c|c|}
\hline Sample & Heating rate, ${ }^{\circ} \mathrm{C} / \mathrm{min}$ & $T_{\text {onset }}{ }^{\circ} \mathrm{C}$ & $T_{50^{\prime}}{ }^{\circ} \mathrm{C}$ & $T_{\max }{ }^{\circ} \mathrm{C}$ \\
\hline PA11/PPO & $\begin{array}{c}5 \\
10 \\
20 \\
\end{array}$ & $\begin{array}{l}412 \\
423 \\
436 \\
\end{array}$ & $\begin{array}{l}442 \\
458 \\
468 \\
\end{array}$ & $\begin{array}{l}441 \\
455 \\
467 \\
\end{array}$ \\
\hline $1 \mathrm{wt} \% \mathrm{~A}-\mathrm{SiO}_{2}$ & $\begin{array}{c}5 \\
10 \\
20 \\
\end{array}$ & $\begin{array}{l}412 \\
432 \\
437 \\
\end{array}$ & $\begin{array}{l}443 \\
460 \\
468 \\
\end{array}$ & $\begin{array}{l}441 \\
458 \\
466 \\
\end{array}$ \\
\hline $3 \mathrm{wt} \% \mathrm{~A}-\mathrm{SiO}_{2}$ & $\begin{array}{c}5 \\
10 \\
20 \\
\end{array}$ & $\begin{array}{l}414 \\
431 \\
439 \\
\end{array}$ & $\begin{array}{l}448 \\
460 \\
472 \\
\end{array}$ & $\begin{array}{l}456 \\
458 \\
473 \\
\end{array}$ \\
\hline $5 \mathrm{wt} \% \mathrm{~A}-\mathrm{SiO}_{2}$ & $\begin{array}{c}5 \\
10 \\
20 \\
\end{array}$ & $\begin{array}{l}422 \\
433 \\
445 \\
\end{array}$ & $\begin{array}{l}453 \\
465 \\
479 \\
\end{array}$ & $\begin{array}{l}452 \\
467 \\
483 \\
\end{array}$ \\
\hline
\end{tabular}

ity on the other [35]. Therefore, even such nanofillers can increase the crystallization rate of polymers and may cause a reduction in the degree of crystallinity [39].

The thermal stability of PA11, PPO and PA11/PPO blend containing different amounts of $\mathrm{A}-\mathrm{SiO}_{2}$ was investigated by thermogravimetric analysis (TGA) under air flow. One of the parameters that are interesting from TGA curves is the onset of degradation $\left(T_{\text {onset }}\right)$, which is usually taken as the temperature at which $10 \%$ degradation occurs. Fig. 10 shows that PA11 degrades in one single step practically almost without any residue. Moreover, pure PA11 degrades with a large single peak starting around $420^{\circ} \mathrm{C}$ and is completely volatilized at $600^{\circ} \mathrm{C}$. PPO shows better thermal stability, due to much higher $T_{\text {onset }}$ and $T_{\max }$. Comparing the TGA traces in Fig. 10 it can be

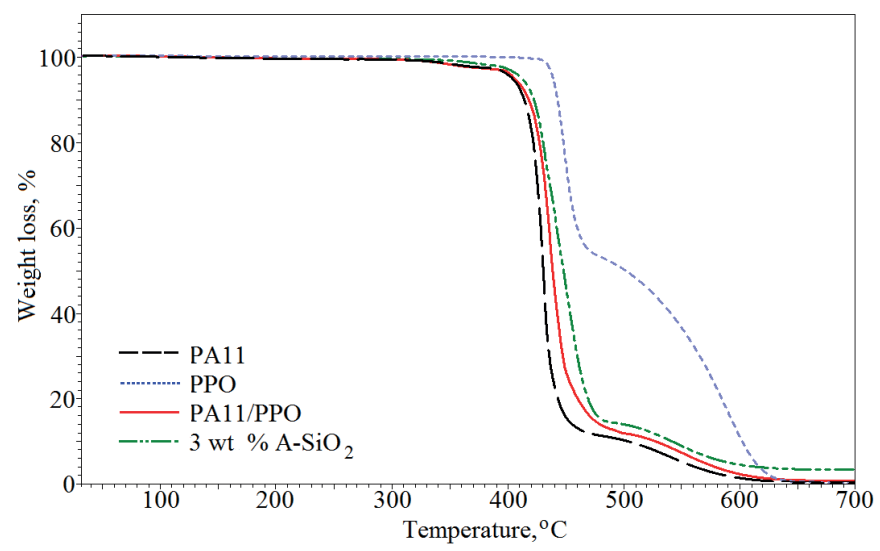

Fig. 10. TGA thermograms of PA11, PPO and PA11/PPO/A-SiO composite recorded with heating rate of $10^{\circ} \mathrm{C} / \mathrm{min}$ seen that the thermal stability of PA11/PPO blend containing $\mathrm{A}-\mathrm{SiO}_{2}$ particles seems to be higher than that of PA11/PPO without silica, indeed weight loss started at higher temperatures. The addition of silica made the TGA response significantly increasing. Indeed, the $T_{\text {onset }}$ and $T_{\max }$ temperatures were higher about $10^{\circ} \mathrm{C}$. However, the effect of silica content was moderate.

The effect of heating rate was studied for the samples containing different amounts of $\mathrm{A}-\mathrm{SiO}_{2}$ in comparison with PA11/PPO blend. The results are presented in Table 6 and Fig. 11. It can be clearly seen that TGA curves shift towards higher temperatures as the heating rate increases. This well-known effect can be explained by the shorter time required by the material to reach a given temperature at a higher heating rate. The shape of the

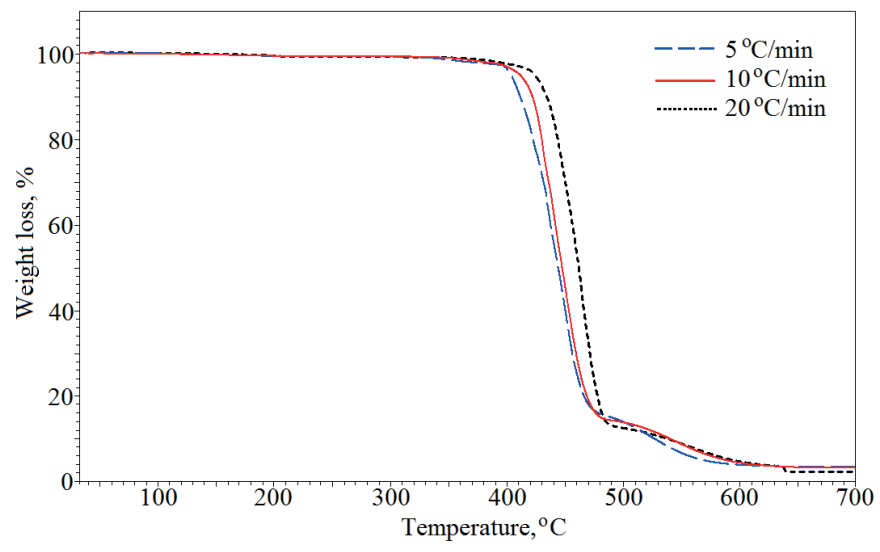

Fig. 11. TGA thermograms of $\mathrm{PA11} / \mathrm{PPO} / \mathrm{A}-\mathrm{SiO}_{2}$ composites recorded with heating rate of 5,10 and $20^{\circ} \mathrm{C} / \mathrm{min}$ 
curves suggests a single step decomposition. However, the global shape of the curves changes with heating rate, especially at early stage of weight loss, suggesting a more complex mechanism with multi step reactions. The final residue of $\mathrm{PA} 11 / \mathrm{PPO} / \mathrm{A}-\mathrm{SiO}_{2}$ composites corresponds to weight content of the silica. It seems that silica does not promote the char formation during the thermo-oxidative degradation of the material.

The results obtained from TGA suggest that the key point of thermo-oxidative process occurs at temperature close to the $T_{\text {onset }}$. At this temperature the stabilization effect of the silica becomes evident and the composites and the PA11/PPO blend behave in a completely different manner.

\section{CONCLUSIONS}

Modified silica having amine functional groups $\left(\mathrm{A}-\mathrm{SiO}_{2}\right)$ was used to improve interfacial adhesion between biobased polyamide 11 and poly(phenylene oxide). $\mathrm{A}-\mathrm{SiO}_{2}$ was prepared by sol-gel process and incorporated into the PA11/PPO 80/20 blend by melt compounding using a twin-screw co-rotating extruder. Modified silica acts as a compatibilizer and reinforcing agent simultaneously, improving the PA11 and PPO miscibility and increasing significantly stiffness, impact strength, and reducing the crystallinity without affecting crystallization temperature of PA11. The particle size of PA11 and PPO phases can be controlled by the content of $\mathrm{A}-\mathrm{SiO}_{2}$ and $\mathrm{A}-\mathrm{SiO}_{2}-\mathrm{g}-\mathrm{PA} 11$ copolymers, which was confirmed by SEM. The interpenetrating networks and the greatest size-reduction of both phases, reflecting the highest impact toughness, were observed for the content of $3 \mathrm{wt} \% \mathrm{~A}-\mathrm{SiO}_{2}$. At higher silica loading, phase inversion and the reappearance of the droplet structure, resulted in a slight decrease in impact strength and significant in elongation at break. TGA showed that silica enhanced the thermal stability of the PA11/PPO blend under thermo-oxidative conditions. However, the effect of $\mathrm{A}-\mathrm{SiO}_{2}$ content was moderate.

\section{ACKNOWLEDGMENTS}

This work was financially supported by project No. WNDPOIG.01.03.01-14-058/09 co-financed by EU (European Regional Development Fund). The authors are very grateful to dr Aneta Lukomska, for her valuable work with the SEM images.

\section{REFERENCES}

[1] Mutlu H., Meier M.A.R.: European Journal of Lipid Science and Technology 2010, 112, 10. https:doi.org/10.1002/ejlt.200900138

[2] Oliver-Ortega H., Granda L.A., Espanish F.X. et al: European Polymer Journal 2016, 84, 481. https://doi.org/10.1016/.eurpolymj.2016.09.062

[3] Bourmaud A., Le Duigou A., Gourier C., Baley C.: Industrial Crops and Products 2016, 84, 151. https://doi.org/10.1016/j.indcrop.2016.02.007
[4] Le Duigou A., Bourmaud A., Gourier C., Baley C.: Composites: Part A 2016, 85, 123. https://doi.org/10.1016/j.compositesa.2016.03.014

[5] Gourier C., Bourmaud A., Le Duigou A., Baley C.: Polymer Degradation and Stability 2017, 136, 1. https://doi.org/10.1016/j.polymdegradstab.2016.12.003

[6] He X., Yang J., Zhu L. et al.: Journal of Applied Polymer Science 2006, 102, 542. https://doi.org/10.1002/ app.24281

[7] Mancic L., Pontón P.I., Letichevsky S. et al.: Composites Part B 2016, 93, 153. https://doi.org/10.1016/j.compositesb.2016.03.028

[8] Sahnoune M., Taguet A., Otazaghine B. et al.: European Polymer Journal 2017, 90, 418. https://doi.org/10.1016/j.eurpolymj.2017.03.008

[9] Li Y., Yang G.: Journal of Materials Science 2010, 45, 987. https://doi.org/10.1007/s10853-009-4029-z

[10] Jeziórska R., Wielgosz Z., Szadkowska A. et al.: Polimery 2016, 61, 710.

https://doi.org/10.14314/polimery.2014.201

[11] Oliveira M.J., Cramez M.C., Garcia C.B. et al.: Journal of Applied Polymer Science 2008, 108, 939. https://doi.org/10.1002/app.27344

[12] Martino. L., Basilissi L., Farina H et al.: European Polymer Journal 2014, 59, 69. https://doi.org/10.1016/j.eurpolymj.2014.07.012

[13] Chiang C.R., Chang F.C.: Journal of Polymer Science 1996, 61, 2411.

h t t p s : / / o i o r g / 10.1002 / ( S I C I ) 1097 4628(19960926)61:13<2411::AID-APP21>3.0.CO;2-5

[14] Chiang C.R., Chang F.C.: Polymer 1997, 38, 4807. https://doi.org/10.1016/S0032-3861(96)00015-8

[15] Jeziorska R., Abramowicz A., Szadkowska A. et al.: Journal of Renewable Materials 2018, 6(7), 772. https://doi.org/10.7569/JRM.2018.634114

[16] Jeziorska R., Swierz-Motysia B. et al.: Polimery 2009, 54, 647. https://doi.org/10.14314/polimery.2009.647

[17] Jeziorska R., Swierz-Motysia B., Zielecka M. et al.: Journal of Applied Polymer Science 2012, 125, 4326. https://doi.org/10.1002/app.36579

[18] Studzinski M., Jeziorska R., Szadkowska A., Zielecka M.: Polimery 2014, 59, 625. https://doi.org/10.14314/polimery.2014.625

[19] Pat. PL 198188 (2008).

[20] Zielecka M., Bujnowska E., Suwala K., Wenda M.: Sol-Gel-Derived Silicon-Containing Hybrids. In Recent Applications in Sol-Gel Synthesis, $1^{\text {st }}$ ed.; Editor: Chandra, U.; InTech, USA, 2017, pp. 123 , ISBN 978-953-51-3246-2, 05.07.2017.

[21] Pat. PL 224607 (2017).

[22] Ricou P., Pinel E., Juhasz N.: Advances in X-ray Analysis 2005, 48, 170.

[23] Sahnoune M., Taguet A., Otazaghine B. et al.: European Polymer Journal 2017, 90, 418.

https://doi.org/10.1016/j.eurpolymj.2017.03.008

[24] Zou H., Wang, K., Zhang Q. et al.: Polymer 2006, 47, 7821. 
https://doi.org/10.1016/j.polymer.2006.09.008

[25] Bikiaris D. N., Vassiliou A., Pavlidou E., Karayannidis G.P.: European Polymer Journal 2005, 41, 1965. https://doi.org/10.1016/j.eurpolymj.2005.03.008

[26] Li Y.J., Shimizu H.: Polymer 2004, 45, 7381. https://doi.org/10.1016/j.polymer.2004.09.018

[27] Fu S.Y., Feng X.Q., Lauke B. et al.: Composites Part B: Engineering 2008, 39, 933. https://doi.org/10.1016/j.compositesb.2008.01.002

[26] Mancic L., Osman R.F.M., Costa A.M.L.M. et al.: Materials \& Design 2015, 83, 459. https://doi.org/10.1016/j.matdes.2015.06.059

[29] Sallem-Idrissi N., Van Veltchem P., Sclavons M.: Journal of Polymers and the Environment 2018, 26, 4405. https://doi.org/10.1007/s10924-018-1311-7

[30] Nanni A., Messori M.: Composites Science and Technology 2020, 188, 107974 https://doi.org/10.1016/j.compscitech.2019.107974

[31] Sangroniz L., Palacios J.K., Fernández M. et al.: European Polymer Journal 2016, 83, 10. https://doi.org/10.1016/j.eurpolymj.2016.07.026

[32] Shen Y., Guo Z., Cheng J., Fang Z.: Journal of Applied Polymer Science 2010, 116, 1322. https://doi.org/10.1002/app.31540
[33] Hoseini A.H.A., Arjmand M., Sundararaj U., Trifkovic M.: European Polymer Journal 2017, 95, 418. https://doi.org/10.1016/j.eurpolymj.2017.08.037

[34] Jeziorska R., Swierz-Motysia B., Szadkowska A. et al.: Polimery 2011, 56, 809. https://doi.org/10.14314/polimery.2011.809

[35] Zhou R. J., Burkhart T.: Journal of Materials Science 2011, 46, 1228. https://doi.org/10.1007/s10853-010-4901-x

[36] Chiang C.R., Chang F.C.: Journal of Polymer Science Part B: Polymer Physics 1998, 36, 1805.

h t t p s: // d o i org / 10.1002 / ( S I C I ) 1099 0488(199808)36:11<1805:AID-POLB2>3.0.CO;2-P

[37] Ray S.S., Okamoto M.: Progress in Polymer Science 2003, 28, 1539.

https://doi.org/ 10.1016/j.progpolymsci.2003.08.002

[38] Pelech I., Kwiatkowska M., Jedrzejewska A. et al.: Polimery 2017, 62, 101. DOI: dx.doi.org/10.14314/polimery.2017.101

[39] Wu D., Wang X. Jin R.: European Polymer Journal 2004, 40, 1223.

https://doi.org/10.1016/j.eurpolymj.2004.01.004

Received 20 VI 2021. 